\title{
2.2 Генезис кримінальної відповідальності за незаконну порубку лісу, захисних та інших лісових насаджень у законодавстві України: історико- правовий аспект
}

Економічне та екологічне значення лісів і лісонасаджень у життєдіяльності суспільства виступають першими факторами, які обумовлюють необхідність забезпечення дбайливого до них ставлення, так само належної їх охорони, у тому числі кримінально-правовими засобами. Серед кримінальних правопорушень, що вчиняються у природному середовищі, найбільшу суспільну небезпеку як своєю розповсюдженістю, так і завданими матеріальними збитками, а також нанесеною природі шкодою, в першу чергу представляє порубка лісу, захисних та інших насаджень.

Перші правові підстави визначення відповідальності за кримінальне правопорушення, що аналізується, в українському законодавстві були закріплені давно, проте, їх упорядкування та цілеспрямоване вдосконалення фактично було розпочато лише після кодифікації національного кримінального законодавства, яка була введена в дію постановою Всеукраїнського Центрального Виконавчого Комітету (далі - ВУЦВК) від 23 серпня 1922 року „О введении в действие Уголовного кодекса УССР" с 15 сентября 1922 года [56, с. 450]. Разом з тим, перший Кримінальний кодекс УРСР (далі - КК УРСР 1922) не був позбавлений в цій частині недоліків. Так, статтею 99 КК, яка включала лише одну частину, водночас кримінально караними, поряд 3 хижацькою експлуатацією та знищенням лісів, визнавалися ведення лісового господарства 3 порушенням встановленого плану, полювання i риболовля у недозволений час i y недозволених місцях навколишнього природного середовища, недозволеними способами і прийомами, та інші дії, що об'єднувалися лише такою ознакою, як завдання ними збитку оточуючому природному середовищу [56, с. 471]. Циркуляром № 30 Верховного Суду УРСР від 02 червня 1924 року „О подсудности дел о самовольной пастьбе скота в лесах” було дано роз'яснення, що умисна потрава лісових культур, молодого лісу, розплідників, трави, посівів, умисна пастьба худоби у недозволених місцях, а також умисна пастьба видів 
худоби, недозволених до випасу у лісах (кіз та ін.) переслідується у порядку ст. 99 КК [56, с. 646]. Перелік протиправних діянь, що визнавалися злочинними за ст. 99 КК, було доповнено постановою Всеукраїнського Центрального Виконавчого Комітету і Ради Народних Комісарів (далі - ВУЦВК і РНК) від 09 вересня 1925 року „Об изменении ст. 99 Уголовного кодекса УССР”. До таких були також віднесені: розкрадання зрубаного лісу, сінокосіння, самовільна постановка пчельників, недозволене підсікання дерев та всяке інше незаконне користування лісами або землями державного лісового фонду, незалежно від того, в чиєму користуванні вони були, та ін. [56, с.715-716]. Але прикладна значимість зазначеної постанови цим не вичерпувалась. В ній було зроблено спробу диференціації відповідальності як за визнані адміністративними, так і кримінальними правопорушення, скоєні у лісах, лісонасадженнях та ін. Адміністративними визнавалися вчинені у зазначених місцях правопорушення, у випадках, якщо завдані правопорушником збитки, які обчислювалися за нормальними таксами або за його дійсною вартістю, не перевищували 15 карбованців. Але вже при цьому було визначено диференційовану відповідальність у вигляді штрафу в порядку накладення адміністративних стягнень районними виконавчими комітетами, у тому числі: а) за лісопорушення штраф накладався в межах, визначених постановою ВУЦВК і РНК від 19 серпня 1925 року „О таксах штрафних взысканий за лесные правонарушения”; б) за інші зазначені у ст. 99 КК правопорушення передбачався штраф у межах, що не перевищували триразового розміру заподіяного збитку. Всі інші правопорушення, що вчинялися в лісах і екологічній сфері та підпадали під ознаки ст. 99 КК визнавалися кримінальними правопорушеннями та їх скоєння тягло покарання у вигляді позбавлення волі або примусових робіт на строк до шести місяців або штрафу, причому у кожному такому випадку з відібранням незаконно здобутого та конфіскацією знарядь злочину [56, с. 715-716].

Подальше вдосконалення критеріїв диференціації кримінальної відповідальності за лісові правопорушення було продовжено постановою ВУЦВК і РНК УРСР від 23 лютого 1927 року „Об изменении ст. 99 Уголовного 
кодекса УССР и о дополнении указанного кодекса статьями $99^{1}$ и $99^{2 \%}$, наслідком чого стало включення до структури ст. 99 трьох частин, згідно з якими було встановлено відповідальність за: а) порушення законів і правил, встановлених в інтересах охорони лісів від розкрадань і винищення, якщо завдані збитки, які обчислювалися за нормальними таксами, не перевищували 15 карбованців (частина 1 статті) (штраф, який накладався у адміністративному порядку, 3 конфіскацією знарядь злочину); б) ті самі дії, якщо завдані збитки перевищували 15 карбованців або якщо вони були скоєні особами, до яких раніше було застосовано заходи адміністративного впливу за лісові правопорушення (частина 2 статті) (позбавлення волі або примусових робіт на строк до шести місяців або штраф до 200 карбованців і конфіскація у всіх випадках знарядь злочину); в) ті ж діяння, вчинені у вигляді промислу (частина 3 статті) (позбавлення волі на строк до трьох років з конфіскацією частини майна або без такої конфіскації та заборона перебувати у лісових місцевостях) [57, с. 292].

В основу ст. 82 Кримінального кодексу УРСР, введеного в дію з 01 липня 1927 року в редакції 1927 року (далі - КК УРСР 1927 р.), було закладено правові положення відповідальності за лісові правопорушення, які передбачалися ст. 92 КК УРСР 1922 р. (в редакції від 27 лютого 1927 року), але з виключенням норми, яка передбачала адміністративну відповідальність за такі правопорушення у випадках, якщо завданий збиток, що обчислювався за нормальними таксами, не перевищував 15 карбованців. Таким чином, ст. 82 КК УРСР 1927 р. структурно включала дві частини, що передбачали відповідальність за простий та кваліфікований склад розкрадання і винищення лісів, у тому числі: а) простий склад кримінального правопорушеннями складало порушення законів і правил, встановлених в інтересах охорони лісів від розкрадання і винищення, якщо завданий збиток, що обчислювався за нормальними таксами, перевищував 15 карбованців або воно було вчинено особою, яку раніше було притягнуто до адміністративної відповідальності за лісові правопорушення (міру покарання складали позбавлення волі на строк до шести місяців або примусові роботи на той же строк, або штраф до 200 карбованців, але у всіх випадках з конфіскацією 
знарядь злочину); б) кваліфікований склад - ті самі дії, які вчинялися у вигляді промислу (міру покарання було визначено у вигляді позбавлення волі на строк до трьох років з конфіскацією частини майна або без такої конфіскації та заборони перебувати у лісових місцевостях) [57, с. 338-339].

Постановою ВУЦВК і РНК УРСР від 17 жовтня 1928 року „Об изменении и дополнении Уголовного кодекса УССР” було змінено й редакцію ст. 82 КК УРСР 1927 р., в результаті чого за ч. 1 статті покаранню підлягало порушення законів і правил, встановлених в інтересах охорони від розкрадання і винищення лісів, парків, скверів, садів і деревних насаджень вздовж вулиць, доріг, рік, ставків та ін., якщо завданий збиток, що обчислювався за нормальними таксами, перевищував п’ятнадцять карбованців або воно було вчинено особами, до яких вже раніше було застосовано заходи впливу за вказані правопорушення в адміністративному або судовому порядку (позбавлення волі на строк до шести місяців, або примусові роботи на той же строк, або штраф до трьохсот карбованців, та у всіх випадках з конфіскацією знарядь злочину); за ч. 2 статті передбачалося покарання за ті ж дії, вчинені у вигляді промислу (міру покарання було визначено у вигляді позбавлення волі на строк до трьох років 3 конфіскацією майна або без такої конфіскації і заборони перебувати у лісових місцевостях) [57, с. 491].

Своєю постановою від 13 грудня 1931 року „Об ответственности должностных лиц, землепользователей и лесопользователей-единоличников и других лиц за преступное отношение к лесосооружениям, лесонасаждениям и древонасаждениям» Наркомюст УРСР, звернувши увагу на величезне значення збереження лісоспоруд і розповсюдження лісонасаджень та деревонасаджень, роз'яснив, що посадові особи державних, громадських, кооперативних установ, підприємств і організацій підлягали відповідальності за ст. 99 КК УРСР за злочинне і недбале ставлення до виконання своїх обов'язків відносно лісоспоруд, лісонасаджень і деревонасаджень, що потягло: а) порушення затверджених планів господарства та виробничих планів в лісах, що знаходилися в їх користуванні; б) порушення встановлених Наркомземом правил господарювання 
в лісах державного та місцевого значення; в) невиконання обов'язків, покладених на землекористувачів, відносно лісонасаджень, закріплення та господарського освоєння непридатної землі за планом, встановленим Наркомземом, тощо [57, с. 573-574].

Але вже 20 травня 1932 року, з метою посилення боротьби 3 лісовими правопорушеннями ВУЦВК і РНК УРСР своєю постановою „Об изменении ст. 82 Уголовного кодекса УССР и статей 74, 75 и 77 Административного кодекса УССР" виклав ст. 82 у новій редакції, згідно з якою за ч. 1 статті передбачалась відповідальність за порушення законів і правил, встановлених в інтересах охорони від розкрадання і винищення лісів, чагарників, парків, скверів, садів, деревних розплідників, плантацій, полезахисних і снігозатримуючих насаджень та деревних насаджень вздовж вулиць, доріг, рік, ставків та ін., якщо завданий збиток, що обчислювався за нормальною таксою, перевищував 50 карбованців або порушення було вчинено особами, до яких раніше було застосовано заходи впливу за вказані правопорушення в адміністративному або судовому порядку (міра покарання була визначена у вигляді примусових робіт або штрафу до однієї тисячі карбованців, та у всіх випадках з конфіскацією знарядь злочину); за ч. 2 статті передбачалася відповідальність за ті ж дії, вчинені у вигляді промислу (покарання - позбавлення волі на строк до п’яти років з конфіскацією майна або без такої конфіскації та заборона перебувати у лісових місцевостях лісокультурної зони) [57, с. 581-582].

Таким чином, на початок $60-\mathrm{x}$ років $\mathrm{XX}$ століття, тобто до моменту прийняття і введення в дію Кримінального кодексу УРСР 1960 року, в Україні вже був накопичений певний досвід диференціації відповідальності за кримінальні правопорушення в сфері оточуючого середовища, у т.ч. за лісові правопорушення. 3 його врахуванням і була сконструйована включена до КК УРСР 1960 року ст. 160, яка складалася 3 двох частин и передбачала відповідальність за незаконну порубку лісу. Простий склад злочину включав незаконну порубку лісу на корню у всіх лісах державного значення, колгоспних лісах i в межах захисних лісових полос, яка завдала лісовому господарству 
збиток, що перевищував десять карбованців за таксовими цінами, встановленими для відпуску лісу на корню населенню у даній місцевості (каралася така незаконна порубка виправними роботами на строк до одного року або штрафом до ста карбованців, з конфіскацією незаконно зрубаної деревини). За ч. 2 статті (кваліфікований склад злочину) підлягали відповідальності особи, винні у вчиненні тієї ж дії, якщо вона завдала великій збиток або вчинена систематично (така дія каралася позбавленням волі на строк до п'яти років 3 конфіскацією незаконно зрубаної деревини) [57, с. 793].

Набуття чинності КК Української РСР 1960 р. не призупинило пошук шляхів щодо подальшого вдосконалення кримінально-правової норми, яка визначала правові підстави покладання відповідальності за незаконну порубку лісу. Вже Указом Президії Верховної Ради Української РСР від 10 вересня 1962 p. „Про внесення змін i доповнень до Кримінального та Кримінальнопроцесуального кодексів Української РСР” до аналізованої ст. 160 КК було внесено певні зміни та доповнення. За ч. 1 ст. 160 КК в ії новій редакції караною було визнано також незаконну порубку лісу у вказаних лісах, що завдала лісовому господарству шкоди у меншому, ніж десять карбованців, розмірі, але вчинена повторно (міра покарання була посилена - було передбачено також позбавлення волі на строк до одного року, а також збільшено суму штрафу до 200 карбованців). В ч. 2 ст. 160 КК таку кваліфікуючу ознаку, як здійснення порубки лісу систематично, було замінено на здійснення порубки лісу у вигляді промислу (санкцію норми було залишено без змін) [58].

Аналізована стаття вимагала й інших змін і доповнень, проте, ії подальше вдосконалення було призупинено до початку 80 -х років минулого століття. У зв'язку з цим дещо запоздалими, але успішними слід визнати зміни і доповнення, внесені до ст. 160 КК Указом Президії Верховної Ради Української РСР № 4571Х від 12 січня 1983 р. „Про внесення змін і доповнень до Кримінального кодексу Української РСР”. Серед внесених позитивних змін і доповнень назвемо, перш за все, визначення дерев i чагарників як предмету таких кримінальних правопорушень. Хоча, як i раніше, склад кримінально караного діяння 
визначався як вчинення цілеспрямованої дії, що викликало і спричинило настання конкретно вираженої шкоди, розміри цієї шкоди в новій редакції ст. 160 КК залежали від призначення та значущості лісів i лісонасаджень у життєдіяльності суспільства і людини. Так, передбачений ч. 1 ст. 160 КК простий склад аналізованого кримінального правопорушення складала незаконна порубка дерев і чагарників: а) у лісах першої групи, що виконують захисні, санітарно-гігієнічні та оздоровчі функції, в лісах заповідників, національних і природних парків, заповідних лісових ділянках, лісах, що мають наукове або історичне значення, природних пам'ятках, лісопарках, якщо шкода перевищує сто карбованців; б) а в інших лісах, що належать до першої групи - двісті карбованців (в обох випадках за таксою, встановленою для обчислення розміру стягнень за шкоду, заподіяну незаконною порубкою і пошкодженням дерев і чагарників); в) або незаконна порубка дерев і чагарників в інших лісах, якщо шкода перевищувала триста карбованців за тією ж таксою; г) також порубка дерев і чагарників у зазначених лісах, що потягла за собою заподіяння шкоди в меншому розмірі, але була вчинена повторно (при цьому строки таких альтернативних видів покарання як позбавлення волі та виправні роботи були залишені без змін; збережена була також конфіскація незаконно добутого, але сума штрафу було збільшено до трьохсот карбованців). Кваліфікуючою за ч. 2 ст. 160 КК була визнана незаконна порубка дерев і чагарників у будь-яких лісах, вчинювана систематично (тобто раніше виконана заміна такої кваліфікуючої ознаки на вчинення подібного правопорушення у вигляді промислу була визнана не зовсім прийнятною) або така, що вчинена вперше, але спричинила велику шкоду (тобто спричинення великого збитку було віднесено до ознак складу кримінального правопорушення, які впливають на його кваліфікацію). Зміни і доповнення торкнулися також санкції ч. 2 ст. 160 КК і полягали в наступному: до залишених без змін позбавлення волі на строк до п'яти років і конфіскації незаконно добутого було додано „або виправними роботами на строк від одного року до двох років, або штраф у розмірі до трьохсот карбованців, а при 
корисливій заінтересованості - штраф у розмірі до однієї тисячі карбованців” [59].

Наступні зміни до аналізованої ст. 160 КК були внесені Законом України № 41/95 ВР від 08.02.1995 року „Про внесення змін до законодавчих актів України щодо застосування кримінальних покарань у вигляді штрафу” та стосувались обчислення розмірів збитків, завданих незаконною порубкою лісу, а також суми штрафу, що накладався в судовому порядку за вчинення таких кримінальних правопорушень. При цьому передбачені ч.ч. 1 ст. 160 КК розміри завданої шкоди, що обчислюється за таксою, встановленою для обчислення розміру стягнень за шкоду, заподіяну незаконною порубкою і пошкодженням дерев і чагарників, що перевищують сто карбованців, двісті карбованців та триста карбованців, було замінено на обчислювані за тією ж таксою розміри шкоди, яка перевищує, відповідно, двісті п'ятдесят, триста та триста п'ятдесят мінімальних розмірів заробітної плати. Зміни було внесено і до санкцій ч.ч. 1 і 2 ст. 160 КК, які полягали у зміні розмірів (суми) штрафів, що накладаються як покарання: а) в ч.ч. 1 ст. 160 КК штраф в розмірі до трьохсот карбованців був замінений штрафом від п'ятдесяти до ста двадцяти мінімальних розмірів заробітної плати; б) при корисливій заінтересованості - замість штрафу у розмірі до однієї тисячі карбованців був передбачений штраф від двохсот до чотирьохсот мінімальних розмірів заробітної плати [60].

Схвалений Верховною Радою України 05 квітня 2001 року і введений в дію з 01 вересня 2001 року новий Кримінальний кодекс заклав основи кримінальноправової політики Української держави, в тому числі у забезпеченні належної охорони оточуючого середовища. Якщо, наприклад, у КК України 1960 р. екологічні злочини розміщувалися у главі VI «Господарські злочини», то у КК 2001 р. правопорушення цієї категорії було виділено в самостійний розділ VIII «Кримінальні правопорушення проти довкілля», в якому розміщена ст. 246 «Незаконна порубка лісу». Перша редакція вказаної статті суттєво відрізнялася від тієї, яка містилася в КК Української РСР 1960 р. за своєю структурою, діями, що утворювали об’єктивну сторону кримінального правопорушення і заходами 
кримінально-правового впливу на винних осіб. По-перше, структурно ст. 246 КК включала лише одну частину, якою визначалася відповідальність за незаконну порубку дерев і чагарників у лісах, захисних та інших лісових насадженнях, що заподіяли істотну шкоду, а також вчинення таких дій у заповідниках або на територіях та об’єктах природно-заповідного фонду, або в інших особливо охоронюваних лісах [61, с. 171]. Кримінально-правовий вплив за перелічені дії складали штраф від п'ятдесяти до ста неоподатковуваних мінімумів доходів громадян або арешт на строк до шести місяців, або обмеження волі на строк до трьох років, або позбавленням волі на той самий строк з конфіскацією незаконно здобутого [61, с. 171-172].

Разом $з$ тим, практика застосування закріплених у ст. 246 КК правових підстав протидії аналізованим кримінальним правопорушенням виявила недостатню їх ефективність, що потягло за собою внесення в цю статтю КК змін і доповнень. Відповідно до Закону України № 2063-VIII від 23.05.2017 «Про внесення змін до деяких законодавчих актів України щодо охорони пралісів згідно з Рамковою конвенцією про охорону та сталий розвиток Карпат», аналізована стаття 246 КК була викладена в новій редакції: а) при збереженій колишній редакції диспозиції норми, яка стала у новій редакції частиною першою статті, розмір штрафу, як альтернативної міри покарання, був визначений в сумі від трьохсот до п’ятисот неоподатковуваних мінімумів доходів громадян (інші передбачені санкцією статті альтернативні види покарань були збережені); б) стаття була доповнена частиною другою, за якою було визначено покарання у вигляді обмеження волі на строк від двох до п’яти років або позбавлення волі на той самий строк за передбачену ч. 1 статті дію, вчинену повторно або за попередньою змовою групою осіб. При цьому законодавець залишив без кримінально-правового реагування супутні незаконній порубці лісу не менш суспільно небезпечні та поширені протиправні діяння, такі, як незаконні перевезення, зберігання та збут незаконно зрубаних дерев або чагарників, що негативно позначалося на ефективності протидії незаконній порубці лісу [62]. 
Тому вже Законом України № 2531-VIII від 06.09.2018 р. «Про внесення змін до деяких законодавчих актів України щодо збереження українських лісів та запобігання незаконному вивезенню необроблених лісоматеріалів» стаття 246 КК була викладена з дуже суттєвими змінами та доповненнями [63]. Перш за все, зазначимо, що, відповідно до нової редакції статтею 246 КК передбачено відповідальність за незаконну порубку лісу, за незаконне його перевезення, зберігання і збут, що й обумовило, з врахуванням характерних для цих дій різноманіття форм прояву, отже, відповідно й кваліфікуючих ознак, структурний поділ самої статті на чотири частини. Простий склад аналізованого правопорушення (ч. 1 статті) складають незаконна порубка дерев або чагарників у лісах, захисних та інших лісових насадженнях, перевезення, зберігання, збут незаконно зрубаних дерев або чагарників, що заподіяли істотну шкоду. Таким чином, у першій частині статті, окрім дій, викликаних незаконною порубкою лісу та лісонасаджень, визначальною ознакою об'єктивної сторони вказано і розмір заподіяної шкоди, який має бути істотним. Альтернативне кримінальне покарання за перелічені кримінальні правопорушення включає штраф від тисячі до тисячі п’ятисот неоподатковуваних мінімумів доходів громадян або арешт на строк до шести місяців, або обмеження волі на строк до трьох років, або позбавлення волі на той самий строк. Передбачені частиною першою статті дії, вчинені повторно або за попередньою змовою групою осіб підлягають кваліфікації за частиною другою статті (за їх вчинення передбачено покарання у вигляді обмеження волі на строк від трьох до п’яти років або позбавлення волі на той самий строк). Але якщо дії, передбачені в частині першій статті, вчинені у заповідниках або на територіях чи об'єктах природно-заповідного фонду, або в інших особливо охоронюваних лісах, такі протиправні дії утворюють особливо кваліфікуючий склад злочину, що кваліфікується по частині третій статті, і тягне покарання штрафом від тисячі п'ятисот до двох тисяч неоподатковуваних мінімумів доходів громадян або обмеження волі на строк від трьох до п’яти років, або позбавлення волі на той самий строк. 
Частиною четвертою статті встановлено відповідальність за вчинення дій, передбачених частинами першою, другою чи третьою цієї статті, якщо вони спричинили тяжкі наслідки (покарання визначено у вигляді позбавлення волі на строк від п'яти до семи років). Таким чином, обов'язковою ознакою дій, що кваліфікуються за частинами першою, другою і третьою статті виступає заподіяння істотної шкоди, а за частиною четвертою статті підлягають кваліфікації ті самі дії, які спричинили тяжкі наслідки. 3 врахуванням цього, в п. 1 примітки до ст. 246 КК було дано роз'яснення поняттю «істотна шкода», що визначено як шкода, що у дві тисячі і більше разів перевищує неоподатковуваний мінімум доходів громадян, або інша істотна шкода, завдана навколишньому природному середовищу в частині забезпечення ефективної охорони, належного захисту, раціонального використання та відтворення лісів. Згідно з п. 2 примітки до статті, тяжкими наслідками були визнані наслідки, які у п'ять тисяч і більше разів перевищують неоподатковуваний мінімум доходів громадян.

Як підтвердила подальша судова практика у справах про незаконну порубку або незаконне перевезення, зберігання, збут лісу, визначені в додатку до ст. 246 КК кількісні показники в поняттях «суттєва шкода» і «тяжкі наслідки» були завищені, що дозволило багатьом порубщикам лісу, а також особам, винним у вчиненні відповідних супутніх кримінальних правопорушень, уникнути обгрунтованого і справедливого покарання за скоєне. I вже Законом України № 2708-VIII від 25.04.2019 «Про внесення змін до деяких законодавчих актів України щодо збереження українських лісів» ці показники були знижені. У новій редакції п. 1 примітки до ст. 246 КК істотною шкодою вважається така шкода, яка у двадцять і більше разів перевищує неоподатковуваний мінімум доходів громадян. Відповідно до п. 2 примітки до вказаної статті КК тяжкими наслідками вважаються такі наслідки, які у шістдесят і більше разів перевищують неоподатковуваний мінімум доходів громадян [64]. 